\title{
A heuristic model for tailoring teacher development to educational reforms: Focusing on ambiguity and conflict generation
}

\author{
Abstract \\ This paper aims to contribute to the theorisation of effective teacher development (TD) provision in \\ a reform context. Based on a literature review, the paper identifies key reform features, i.e., \\ ambiguity and conflict generation, that shape teachers' engagement with pedagogic reforms and \\ suggests a framework for designing TD programmes that address reform-specific needs. It then \\ explores the utility of this heuristic framework through an in-depth case study of implementation of, \\ and perceptions about, eight reforms in two schools in Hong Kong. The case study confirmed that \\ customising the TD provision to perceived reform characteristics could contribute to teachers' \\ positive perceptions of and experience with reforms.
}

\section{KEYWORDS}

Educational reforms, teacher development, reform characteristics, teacher cognition, tailoring teacher development to reforms, a framework for teacher development provision 


\section{Introduction: EduCATIONAL REFORMS, TEACHERS' COGNition}

\section{AND TEACHER DEVELOPMENT}

\subsection{EDUCATIONAL REFORMS}

Considered as tools to ensure the economic competitiveness of a polity, educational reforms aiming to increase the quality of education frequently appear in supranational, state and regional policy agendas (Cummins, 2013; Sahlberg, 2006). Planning and implementing such reforms, ${ }^{1}$ however, may entail considerable visible expenditure (e.g., fiscal resources) and invisible costs (e.g., emotional discomfort or distress). Therefore, rather than assuming that all changes will result in educational and social improvement, the legitimacy of a reform's discursive process (e.g., deciding the agenda of a reform as well as formulation, implementation, and revision of that reform) should be scrutinised. Any educational reform is a struggle of different people's 'values, beliefs, political opinions, and morals' over power and resources (van Veen \& Sleegers, 2006, p. 90), and not all reforms are well planned and designed as is often assumed (Andrews, 2007; Ball, 1990). It is therefore unsurprising that reforms are often, and quite rightly, resisted - this has been covered quite extensively in the literature (e.g., Author, 2017a; Starr, 2011). In this article we take a different perspective by

\footnotetext{
${ }^{1}$ In this discussion, each named reform is treated as a separate event to reflect educational and policy practitioners' common usage of the term, although educational reforms do not have a particular beginning or ending and are continuous and discursive processes, and it is often the case that one reform is repackaged and labelled as another reform (Ball, Maguire, \& Braun, 2012). Likewise, the 'phases' of reforms, such as design and implementation, are discussed discretely despite their interconnectedness and recursive nature, reflecting that the policy cycle is 'the most widely applied framework to organise and systemise the research on public policy' (Jann \& Wegrich, 2007, p. 45).
} 
focusing on a case where the legitimacy of a reform is agreed upon - although the agreement may be temporal and transient.

\subsection{TEACHER COGNITION AND TEACHER DEVELOPMENT IN A REFORM CONTEXT}

Once a reform is allowed to enter the educational landscape, the designers of a reform (e.g., a politician, think tanks, or the Secretary of Education) and their managers (e.g., reform committee members, responsible officers in the Ministry of Education) still need to establish the effectiveness and sustainability of the proposed changes. Considerable research aiming to identify factors to ensure the effectiveness and sustainability of reform implementation has found that teacher development (TD) is one of the crucial factors leading to, and sustaining, fundamental pedagogic changes in individual schools (e.g., Authors, 2011; Author, 2017c; Fullan, 2009; Mourshed, Chijioke, \& Barber, 2010; OECD, 2015; Spillane, 2012). TD ${ }^{2}$ in this paper is seen as a central, inherent component of a policy or reform cycle, which is specifically designed for the reform targeting at a systematic change. Compared with other forms of reform support, such as building necessary infrastructure and resource provision; TD affects teachers, who decide whether to implement the reforms at the individual classroom level (Author, 2017c; Spillane, 2012) as 'interpreters' of reform texts, deciding what features of reforms are to be implemented in what ways, though the degree of freedom is limited by reform features and remints (Rizvi and Kemmis, 1987).

\footnotetext{
${ }^{2}$ The term is sometimes used in a broader sense, incorporating the conditions that enable fundamental TD, such as systematic change and leadership (e.g., Authors, 2011). In this discussion, the term is used in the former, narrower sense.
} 
Of the research findings on $\mathrm{TD}$ in a reform context, three lines of research are pertinent to this study. These are, research on the nature of TD, the usual trajectory and process of TD, and features of TD programmes which promise fundamental and sustainable pedagogic change of teachers. First, research on the nature of TD finds that TD is not simply a matter of cognitive development, it also involves emotion (Hargreaves, 2001; Scott \& Sutton, 2009) - teaching is a matter of identity not simply of day-to-day practice (Author, 2017b). Second, the process of TD in a reform context usually starts with teachers' awareness of the changes required, which may motivate them to obtain relevant knowledge and skills and accept the promoted changes, and then lead to practicing the promoted pedagogy on a daily basis (this does not necessarily transpire in a linear fashion) (Author, 2015; Muijs \& Lindsay, 2008; also see Author, 2017c, for further discussion on TD around pedagogic reforms). Finally, to positively influence teachers' daily practices through TD programmes and to sustain change (e.g., Hill, Beisiegel, \& Jacob, 2013; Waters \& Vilches, 2001), TD programmes should, among others, focus on practice, adopt inquiry-based learning and build a learning community (e.g., Garet, Porter, Desimone, Birman, \& Yoon, 2001; Hammerness, Darling-Hammond, \& Bransford, 2005; Hill et al., 2013). Recent studies on features of TD which can fundamentally change teachers' pedagogy identify one additional feature; that is, the need to tailor TD programmes to the characteristics of educational reforms (e.g., Cheng, 2013; Hayes, 2012). Policy implementation researchers (e.g., Ball et al., 2012; Kan \& Adamson, 2016; Pülzl \& Treib, 2007) also support this need, as different reforms require and bring out different engagement from teachers. However, based on our review of the past 15 years of research on TD in a reform context on Scopus and Google Scholar, little attempt has been made to investigate which features of reforms should be catered to in TD provision as 
well as how the degree of alignment between TD and reform features affects teachers' perceptions of a reform. This paper aims to address this research gap.

This paper is structured in two parts. The first part is a condensed literature review against which the research is structured and the research findings were analysed. The second part, drawing on the empirical data, aims to connect the intellectual background of the research to the empirical world. In this second part, a reform is analysed in terms of features as described and reported by teachers. After all, it is not the objective features - if there exist such things - but the perceived features that determine the degree to which teachers engage with a given educational reform (e.g., Ball et al., 2012; Murray \& Christison, 2012; Spillane, 2004); positive perceptions

of and experience with a reform are prerequisites of a deeper level of implementation and sustainability of a pedagogic reform (e.g., Guskey, 2000; Muijs \& Lindsay, 2008).

The following research questions, therefore, guide this exploratory study:

1. What key features of a reform can predict teachers' engagement with a reform?

2. How can the identified features be addressed in TD to be provided for the reform?

3. Does TD provision figuring in those key features help teachers implement those reforms?

\section{TAILORING TD TO REFORMS FROM TEACHERS' EXPERIENTIAL}

\section{PERSPECTIVE}

\subsection{CRUCIAL REFORM FEATURES SHAPING TEACHERS' ENGAGEMENT WITH REFORMS}

This section aims to identify the crucial reform features that shape teachers' engagement with reforms. This task may seem unachievable, considering the many ways in which a reform can be characterised. For instance, Matland (1995) identified more than 100 features that previous 5 
research reported as affecting the success of a reform. However, the author also suggested two key features that help to project the course of a reform by synthesising the findings from the policy process research of different orientations and drawing on organisational and decisionmaking theories. He singled out ambiguity and conflict generation as the two critical aspects of a reform that in combination determine the responses of actors and subsequent courses of a reform. The importance of these features has also been noted by other researchers as shaping the responses of actors and subsequent courses of a reform to a large degree (e.g., Cheng, 2013; Rubdy, 2008; Wedell, 2009). Thus, this study explores the utility of these two features in capturing the needs generated by different individual reforms.

Matland (1995) postulated the implementation process of reforms, with different combinations of ambiguity and conflict generation. Ambiguity in reform design leads to 'misunderstanding and uncertainties' (p. 158) and may result from a lack of understanding of the situation or absence of collaboration between the relevant parties. Conflicts occur when different actors have incompatible objectives and when their perceived benefits and losses from a reform differ. To abate ambiguity as a source of resistance against a reform, Matland (1995) recommended providing opportunities to learn and experiment with the reform concepts, which often lead reform designers and managers to readjust goals, as well as identifying ways to achieve previously determined goals. A low degree of conflict can be eased by such measures as persuasion or problem solving, whereas the resolution of a high degree of conflict requires mobilising resources, power exertion and coercion.

In applying Matland's (1995) proposed strategies to designing TD programmes to increase the clarity of a reform, the organiser of a TD programme (e.g., the Ministry of 6 
Education or a teacher development institute designated by the government) may want to check whether the necessary knowledge (know-what) and skills (know-how) are provided. That is, whether reform goals have been clearly communicated; the means identified are sufficient to adopt a reform, and if not, whether teachers have opportunities to develop those means themselves. For reforms that have stirred up conflict, identifying the sources of conflict and addressing them - for example, revisiting the goals and implementation process and adjusting them, in addition to persuading teachers of the value of the newly promoted practice, may prove useful. Matland's (1995) suggestion to adopt rewards and punitive measures to solve conflicts, however, seems to have rather limited relevance for this paper. In relation to changes in daily pedagogic practice, it is not feasible to monitor teachers' uptake of a reform and reward or punish them accordingly (see Authors, 2017a for a discussion of the creative, invisible resistance strategies teachers may adopt to resist educational reforms). Furthermore, in the context of Hong Kong where the case studies for this paper was conducted, the government takes a 'soft' approach to TD: teachers are encouraged to engage in professional development activities for at least 150 hours over three years, but this is not mandatory (Tang, 2015b). Teachers' strong collective resistance to previous coercive policies made the Education Bureau avoid coercion in current policies (Tang, 2015a). Hence, this aspect of Matland's (1995) matrix is not included in developing the proposed heuristic model in this paper. 
Reform clarity requires effective communication of policy goals and means. Despite its importance to the successful implementation and sustained impact of reforms (Gunter, Rayner, Butt, Fielding, Lance, \& Thomas, 2007; Leithwood, Jantzi, \& Mascall, 2002), the clear communication of the goals of and vision for a reform and the means of achieving them is often not addressed or realised during periods of policy change (e.g., Authors, 2014, 2015; Markee, 1997; Spillane, 2004). Authors $(2014,2015)$ reported on a one-month TD programme used as a reform diffusion strategy. The programme was designed to incorporate several features of effective TD, including a focus on practical skills (e.g., lesson planning and teaching practice) and the fostering of a professional learning community and inquiry-based learning (e.g., forming a small inquiry group and conducting reform-related, practice-based research). Despite featuring a design that met several of the criteria identified as necessary for an effective TD programme, the programme in question failed to effectively communicate the promoted changes to all teachers. According to the two studies' interviewees, during the certification, mixed messages about the goal of the reform were sent out; this left some teachers confused, which incurred an unnecessary emotional cost. In addition to the effective communication of goals, providing opportunities to obtain the means to effect change, that is, reform-specific knowledge and skills according to individual needs, is necessary for changes at the classroom level (Walters \& Vilches, 2001).

When the knowledge and skills to be learned are abstract, mastering such skills requires an extended period of learning and opportunities to engage in risk-taking and trial-and-error processes. Such exploratory/experiential learning is most effective when mentoring is provided on teachers' trialling in their own schools with regular formative feedback (Lamb, 1995; 
Saunders, 2013; Smith \& Gillespie, 2007), rather than one-off instructions on the new pedagogy. As the trial-and-error process involves feelings of insecurity and uncertainty, teachers need emotional support. For instance, if TD programmes are designed in a way that provides participants with an experience of success and gives a sense of self-efficacy (Kaniuka, 2012; Saunders, 2013), and if they are not held accountable for unsatisfactory student learning outcomes during the initial stage of reform adoption (e.g., Hayes, 2012; Schmidt \& Datnow, 2005; Waugh \& Godfrey, 1993), they may be more willing to try out the new ideas in their own classrooms.

\subsubsection{TD to reduce reform-generated conflicts}

The significant role played by reform agents' beliefs and identities has been repeatedly emphasised in TD research conducted in a reform context. The research has found that actors interpret and translate reforms through their prism of beliefs and identities (e.g., Authors, 2016, 2017b; Ball et al., 2012; Menken \& García, 2010; Spillane, Reiser, \& Reimer, 2002), and refuse to adopt those they do not believe in or perceive as inappropriate (Kiely \& Davis, 2010; Kubanyiova, 2009; Murray \& Christison, 2012; Saunders, 2013; Woods, 1996). Such resistance may indicate the need to revisit the agendas of the reform, as teachers' expertise and local knowledge may lead teachers to take a political and moral stance to resist the reform in the best interest of students (Authors, 2015, 2017a). However, it may not be the case that the newly promoted pedagogy is harmful, but rather that the value of the reform is not established in the minds of the teachers. In the latter case, given their opportunities to critically engage with the 'sedimented' or ritual teaching practice along with their pedagogic beliefs and identities, teachers may see the potential and benefits which the promoted changes bring to the classroom (Day, 
Elliot, \& Kington, 2005; Park \& Sung, 2013; Pennington, 1995; van Veen, Sleegers, \& van de Ven, 2005; Waters, 2009; Yook, 2010). Therefore, when a reform incurs conflicts, providing open discussion and debate opportunities should help all reform stakeholders, designers and teachers alike to examine the value and legitimacy of reform agendas and reason over and decide on the best course for the reform and their course of action (Lamie, 2004; O'Donahue, 2012; Wedell, 2012).

In helping teachers critically engage with their pedagogical beliefs and identities, providing them with opportunities to become explicitly aware of and analyse their pedagogical assumptions and practices may prove useful (Kubanyiova, 2009; Russell \& Munby, 1992). However, this is not a simple matter. The literature identifies some potential methods to lead teachers towards active reflection, including a discussion of critical incidents with colleagues (e.g., Graves, 2009; Kiely \& Davis, 2010; Korthagen \& Kessels, 1999), experiencing reform ideas first-hand (e.g., Pennington, 1996; Sikes, 1992; Vulliamy, Kimonen, Nevalainen, \& Webb, 1997) and conducting school-based action research (Fullan \& Hargreaves, 2013; Hammerness et al., 2005). For instance, teachers can be paired with a critical friend to discuss a particular pedagogical incident that made either of them feel uncomfortable when trying out a particular change. Kiely and Davis (2010), for example, found that discussion through this arrangement of the reasons for the discomfort could help participants become aware of their underlying assumptions and beliefs and make them capable of evaluating them from a new perspective, which may prompt them to change them. Experiencing a new pedagogy first-hand as learners may help teachers to critically review their pedagogical beliefs through bringing "'values clashes" to the surface' (Pennington, 1996, p. 215). Sikes (1992) found that such first-hand 10 
experience made senior teachers more open to adopting the promoted change in their own classrooms.

2.2.3 A heuristic model for tailoring TD to reforms: Focusing on ambiguity and conflict generation

Drawing on Matland's (1995) insights into different types of reform and the research on teacher learning discussed previously, the matrix presented in Table 1 is proposed. It incorporates four types of TD programme, that is, informative, experiential, negotiatory and experiential and negotiatory, to be matched with educational policies of different levels of ambiguity and conflict. The proposed matrix is only a heuristic model aiming to help TD providers make necessary considerations in terms of catering to reform features at the initial design stage.

Table 1 Matrix for custom designing a TD programme to the characteristics of a reform

\begin{tabular}{|c|c|c|}
\hline & \multicolumn{2}{|c|}{ Conflict } \\
\hline & Low & High \\
\hline \multirow{3}{*}{ ב) } & Informative TD & Negotiatory TD \\
\hline & $\begin{array}{l}\text { Provides factual or theoretical knowledge } \\
\text { and trains basic, straightforward skills. } \\
\text { (e.g., talks and information-sharing } \\
\text { seminars) }\end{array}$ & $\begin{array}{l}\text { Focuses on communication, persuasion and } \\
\text { negotiation } \\
\text { (e.g., open discussion and consultation) }\end{array}$ \\
\hline & Experiential TD & Experiential and Negotiatory TD \\
\hline 垔 & $\begin{array}{l}\text { Involves interaction, collaboration and } \\
\text { reflection assisted by peers and mentors (e.g., } \\
\text { workshop, mentoring scheme and peer } \\
\text { support group) }\end{array}$ & $\begin{array}{l}\text { Aims to change attitudes/beliefs and develop } \\
\text { complex knowledge and skills (e.g., } \\
\text { consultations combined with workshops) }\end{array}$ \\
\hline
\end{tabular}


Informative TD

Informative $T D$ programmes mainly brief participants on the required changes, help them to understand factual or theoretical knowledge and provide them with the basic, straightforward skills necessary for reform implementation. Most such programmes take the form of talks and information-sharing seminars conducted in a unilateral, transmissive manner and address a wide range of audiences. Only TD that directly addresses the focal reform constitutes this category of TD; TD remotely related to the reform (e.g., courses on linguistics in relation to a reform concerned with writing pedagogy) is rarely useful for reform adoption. With reference to Matland's (1995) model, this type of TD is appropriate for reforms that involve low degrees of ambiguity and conflict. An example of a pedagogical reform of this type to which informative TD is applied can be found in South Korea. In 2011, the country's Ministry of Education (MOE) instituted an initiative called 'smart learning' or 'U-learning', with nationwide implementation scheduled for 2015. The reform initiative aimed for ubiquitous state education using digitalised textbooks and on-line lessons accessible through smart phones and portable computers (Kim, 2012). Korea's information and communications technology (ICT)-related infrastructure and the use of such technology in people's daily lives are ranked amongst the top five in the world (International Telecommunication Union, 2012; Lee, 2011), and the country has long practised ICT-assisted learning. These factors meant that the goals and means of the 'smart learning' initiative were readily comprehensible to, and easily gained acceptance from, some classroom teachers who had long integrated ICT into their instruction. According to Lee and Lee (2015, p. 77), '[T]he biggest obstacle to implement[ing] smart learning was a lack of sufficient time for teachers to research and prepare for instruction'. For many Korean teachers, the reform involved 
only familiarisation with new software and the apparatuses provided by textbook publishers and communication-related companies, which the government-provided TD offered (Jeong, 2012).

\section{Experiential TD}

If a reform features a higher level of ambiguity, it requires another type of TD. Experiential TD, which involves a considerable degree of interaction and collaboration with experts or peers, such as in workshops, mentoring schemes and peer support groups, provides opportunities for teachers to apply and then reflect on a promoted practice with individualised or contextualised assistance. Taking the aforementioned smart learning reform as an example, some teachers may be comparatively less proficient in ICT; thus, they may find the means of a reform, such as software and electronic devices difficult to use and feel that they must attain a whole new set of skills to design and deliver lessons under the new lesson mode (Heo, Lim, Lee, \& Kim, 2014; Jeong, 2012). Therefore, the reform requires this group of teachers to spend an extended period, learning ICT-assisted pedagogy. They may also need ongoing feedback within their schools to fully grasp the new mode of teaching.

Considering another example that concerns English language teaching in the East Asian context, recent research has suggested that in certain countries such as Japan, the ideology or pedagogical practice of teaching English in a communicative manner — rather than merely conveying knowledge on the vocabulary and grammatical rules of the language — which has been promoted for more than two decades, is now widely accepted, at least in principle (e.g., Hu \& McKay, 2012; Nishino, 2008; Sakui, 2004; Yook, 2010). For the current teaching force in 
those countries, pedagogy-related reforms are now simply a matter of learning how to practise the new pedagogy, although doing so requires long-term, iterative, practice-based TD.

Negotiatory TD

As noted previously, some educational reforms incur conflict between newly promoted changes and teachers' beliefs and identities, leading them to question the legitimacy of the goals and means of those reforms. A different kind of TD that focuses on communication, persuasion and negotiation may provide suitable opportunities to address the conflicts involved. Negotiatory TD includes open discussion and consultation during which teachers and reform designers or implementers discuss the agenda for narrowing the gap between changes and stakeholders' beliefs/identities. The end result is either teachers adopting the suggested changes or the reform initiators or managers revising the reform to reflect suggestions from teachers with local expertise. For instance, Teacher Appraisal for Professional Development, a South Korean scheme that has been in effect since 2010 with the aim of improving general teaching practice, was initially highly controversial, and it took 10 years of persuasion before it was implemented. This scheme involves observation of lessons by parents and colleagues in addition to supervisors. Different subject teachers experienced the observation element differently. For instance, many English teachers thought that during the observation they had to use English as their medium of instruction; this affected their daily teaching, as they felt they could not use English on the observed day only, and risk being questioned about their integrity by the students (Authors, 2015). The scheme also requires parents and students to evaluate teachers using a satisfaction survey (Ministry of Education Science and Technology, 2012). This component was and remains 
extremely controversial as it shifts the conceptualisation of the teacher from one of authority and expert to one of service provider (Im, 2008; Jeon, 2010). Originally proposed in 2000, teachers fought the scheme through various measures before it was finally instituted in 2010 (Jeon, 2010; Yi \& Kwak, 2009). Rather than abandoning the scheme, the MOE began experimenting with different ideas for implementing it in 2005 (Kim, 2011). It also launched an open consultation with various stakeholders in each region of the country (e.g., Korea Educational Development Institute, 2010), and ultimately revised the scheme to reflect some concerns of both teachers and teacher associations (Hyun, Hwang, Kim, Jang, \& Han, 2010). During this period of negotiation, both regional educational offices and the MOE provided TD sessions in which teachers from schools that had implemented the scheme discussed their experience with it and those from other schools asked questions and raised concerns (e.g., Seoul Gangnam District Office of Education, 2010). Surveys were also conducted to gather the opinions of various stakeholders (e.g., Seoul Metropolitan Office of Education (SMOE, 2010), and the MOE created a host website (http://mtf.edunet4u.net:8889/tf/bbs/atcl/main.do) to which each regional office could link its own website (e.g., http://sen.go.kr/tae/web/services/bbs/bbsList.action?bbsBean.bbsCd=160 for the SMOE). These websites allowed teachers to ask questions and raise concerns, which were then answered by responsible staff members in the regional educational offices, as well as obtain relevant resources and information. Although the scheme remains unpopular, maintaining twoway communication has made teachers view the scheme more favourably and it has been recommended as a means of helping the scheme to take root in the local educational context (Kim, 2011; Hyun et al., 2010). Once again, however, some individual schools and teachers may creatively engage with the scheme, rather than literally following the prescriptions, appropriating 15 
the scheme and altering it without drawing the government's attention, because their beliefs conflict with the scheme causing discomforts, but discussion of such creative subversion is beyond the scope of this paper (cf. Author, 2017a; see also Hall and Noyes, 2009).

\section{Experiential and negotiatory TD}

Although an increase in ambiguity can be a means of reducing conflict, reforms may be characterised by high degrees of conflict and ambiguity, as Matland (1995) noted. In fact, a large number of educational reforms that aim to innovate practices fall into this category, as they involve multidimensional changes, including the transformation of beliefs, teaching and learning materials and pedagogic practice (Fullan, 2001). Thus, teachers often need to reconceptualise teaching and learning and their role in the classroom, as well as learn to translate reform concepts into practice in a way that suits their own teaching context, including student intake, the attitude of the community towards education and many other factors (Ball et al., 2012). Reforms subsumed under this category entail the development of complex knowledge and skills that are difficult to acquire through one-off, transmissive sessions and also require negotiation between reform architects and actors. A combination of experiential and negotiatory TD, either concurrently or subsequently, that takes the form of open discussion and consultation accompanied by on-going, application-focused learning can address the needs of teachers generated by this type of reform.

TD provision for reforms of this final type, however, often fails to address the issues of complexity and conflict. Still, there are rare examples of reforms that address both of these needs documented in the reform literature. The Qualitative Understanding: Amplifying Student 
Achievement and Reasoning project, a mathematics reform in the US aimed at reconceptualising mathematics lessons, is a case in point. This reform, which required a shift from resultsorientated pedagogy to cognition-focused teaching emphasising reasoning and communication skills, was characterised by its high degrees of ambiguity and conflict. Stein, Silver and Smith (1998) described the reform as convoluted and unstructured and in need of '[a] consistent and detailed image of instructional practices and programmes' (p. 19). Despite the high degree of ambiguity attached to the means of the reform, its conflict levels also remained high, as it required teachers to develop lessons collaboratively, and those in a case study conducted by Stein et al. (1998) tended to 'work in isolation and with little or no motivation to change' (p. 20).

Later, however, the reform proved successful in changing teachers' beliefs and instructional practices (Fennema et al., 1996; Stein et al., 1998). Fennema et al. (1996) described in detail the TD provision made for the reform as comprising elements that addressed both ambiguity and conflict. That provision involved 20 training sessions in which teachers explored, discussed and reflected on ways to put the new pedagogy into practice using authentic materials. Teachers also had opportunities to express their concerns about content coverage and selection in follow-up discussion sessions with experienced teachers who helped them to view the related issues from a new perspective. The reform was also accompanied by fiscal and other forms of support. For example, teachers were given release time, credits for graduate degrees and honoraria to participate in training, and teacher mentors visited schools regularly for three years to offer assistance. Although the TD provision in this case was rather idealistic in that not many reforms can afford such thorough TD and support programmes due to resource limitations, it serves as an exemplar demonstrating the benefits of aligning TD with reform idiosyncrasies. 


\section{CASe STUdy: UTILity OF THE FRAMEWORK}

This part of the paper aims to examine the utility of the hypothetical framework through a case study that explored the relationships between the perceived reform characteristics (focusing on ambiguity and conflict generation), TD types (based on the proposed framework) and teachers' perceptions of eight reforms across two schools. The relationship between the perceptions of a reform and the degree of customisation of TD to the reform's features was analysed in this case study.

Multiple case study approach (Stake, 2005) was chosen as this study aims to gain indepth understanding of the cases, i.e., reforms, which unfold over time in specific contexts (Flyvbjerg, 2011; Yin, 2009). The approach was also deemed suitable for this study which investigates reforms as perceived and experienced by teachers, because, as a case study approach is often closely linked with the constructivist approach (Duff, 2008), effectively capturing "participants' lived experiences of, thoughts about and feelings for, a situation" (Cohen Manion, \& Morrison, 2011, p. 290). We chose reforms which were at different stages as cases - some just starting and others having been implemented over a decade, in order to gain better understanding of reform evolvement and reasons for them (McNeil \& Coppola, 2006). We also present the stories of the reforms from the perspectives of two schools, these schools also being cases, to provide better in-depth understanding situated within the respective context (Denzin \& Lincoln, 2011). Thus, the reforms became cases within cases.

\subsection{CASES}

3.1.2 Case reforms 
To provide background, there have been a number of major educational reforms in Hong Kong since 1997, when Hong Kong was reunified with China. The reforms have been characterised by, among other factors, learner-centred education, whole-person development and $21^{\text {st }}$ century skills such as communication and critical thinking. The eight case reforms, which were reported as major reforms that were implemented in the case schools, are summarised in Table 2 . The table includes the names and aims of the reforms, the years in which they were first implemented and other referential notes.

Table 2 Major government-led reforms implemented in the case schools for the past 15 years

\begin{tabular}{|c|c|c|c|}
\hline Reforms & Aims & Year & Notes \\
\hline $\begin{array}{l}\text { English as the } \\
\text { Medium of Instruction } \\
\text { (EMI) }\end{array}$ & $\begin{array}{l}\text { The medium of instruction } \\
\text { (MOI) should be English in } \\
\text { designated schools }\end{array}$ & 1997 & $\begin{array}{l}\text { The government-level policy, the } \\
\text { Medium of Instruction Guidance, } \\
\text { designated the MOI of secondary } \\
\text { schools, making one third of schools } \\
\text { EMI schools and the rest Chinese as } \\
\text { the Medium of Instruction (CMI) } \\
\text { schools }\end{array}$ \\
\hline $\begin{array}{l}\text { Collaborative } \\
\text { Learning (CL) }\end{array}$ & $\begin{array}{l}\text { To promote student-centred } \\
\text { peer-supported learning in } \\
\text { small groups }\end{array}$ & 2000 & $\begin{array}{l}\text { Teachers often interpret this as small } \\
\text { group learning. }\end{array}$ \\
\hline $\begin{array}{l}\text { Information } \\
\text { Technology (IT) }\end{array}$ & $\begin{array}{l}\text { To integrate IT into learning } \\
\text { and teaching at schools }\end{array}$ & 2000 & \\
\hline $\begin{array}{l}\text { New Senior } \\
\text { Secondary Curriculum } \\
\text { (NSSC) }\end{array}$ & $\begin{array}{l}\text { To update the national } \\
\text { curriculum to reflect } 21^{\text {st }} \\
\text { century educational ideals and } \\
\text { needs }\end{array}$ & 2009 & $\begin{array}{l}\text { This was also paired with the New } \\
\text { Academic Structure, which changed } \\
\text { the education years from } 6-3-4-3 \text { to } 6- \\
\text { 3-3-4, lengthening university } \\
\text { education to } 4 \text { years. }\end{array}$ \\
\hline $\begin{array}{l}\text { School-based } \\
\text { Assessment (SBA) }\end{array}$ & $\begin{array}{l}\text { To incorporate assessment at } \\
\text { individual schools into the } \\
\text { Hong Kong Diploma of } \\
\text { Secondary Education } \\
\text { (HKDSE) Examination }\end{array}$ & 2012 & $\begin{array}{l}\text { The introduction of SBA across } \\
\text { different subjects was staggered. }\end{array}$ \\
\hline HKDSE & $\begin{array}{l}\text { To measure students' } \\
\text { achievement during secondary } \\
\text { education }\end{array}$ & 2012 & $\begin{array}{l}\text { Used for admission to the tertiary } \\
\text { education. It replaced the preceding } \\
\text { two-tier exam system. }\end{array}$ \\
\hline Liberal Studies (LS) & $\begin{array}{l}\text { To develop } 21^{\text {st }} \text { century skills } \\
\text { including critical thinking }\end{array}$ & 2012 & Part of the NSSC. \\
\hline $\begin{array}{l}\text { Other Learning } \\
\text { Experience (OLE) }\end{array}$ & $\begin{array}{l}\text { To promote non-academic, } \\
\text { experiential learning }\end{array}$ & 2012 & Part of the NSSC. \\
\hline
\end{tabular}




\subsubsection{Case schools}

The schools investigated were government-funded schools that followed the territory-wide curriculum. Two revealing cases were selected, as the schools practised very different approaches to $\mathrm{TD}^{3}$, while the other factors which have been found to significantly affect reform implementation such as school context (e.g., prestige of the school, student intake, teacher workforce) and vision (e.g., Ball et al., 2012; Woods, 2012) were comparable. The two schools were highly prestigious 'band 1' or elite schools using EMI. Both were aided or governmentsponsored schools, although one recently turned itself into a direct subsidy school, allowing it to collect school fees from parents. Teachers were also similar in terms of their professional credentials and experiences. The schools both shared the vision of whole-person development, which they promoted by offering a wide range of extra-curricular activities.

A comparison of TD in the two schools shows that while both schools provided financial support to help teachers engage in the TD they selected, school 1 was more generous in terms of time - teachers in School 1 had the option to take one-year paid study leave, in contrast to the usual 5-week which reflects the typical length of professional development courses commissioned by the Education Bureau. The degree of systematic integration of the TD into teachers' work lives was also different. In School 1, the principal incorporated TD into the whole school system by linking it to appraisal and supporting it with a mentorship scheme, which she

\footnotetext{
${ }^{3}$ In Hong Kong, the TD is largely left to the discretion of individual schools (Advisory Committee on Teacher Education and Qualifications, 2009), which results in significant difference in practice across schools.
} 
led. In School 2, the principal left the decision about whether to participate in TD to the discretion of teachers. As the principals explained:

[When I first came to this school,] one thing I started looking at was making use of staff development. I started looking at staff development and appraisal, what we call Staff Development and Appraisal and Promotion Policy...I did a lot of mentoring. I had a mentoring system; I set a standard...I adhered to observing. All this is a whole system. (Principal, School 1)

My school does not provide much professional development...Most professional development maybe takes place outside this school. (Principal, School 2)

Both schools formed a committee to oversee the TD activity of teachers, however, the authority and resources of the committee differed between the two schools. In School 1, for example, the committee worked as a bi-directional communication channel between teachers and senior management. Through the committee, teachers expressed their views of their TD needs generated by the reforms and the committee planned relevant support accordingly. In contrast, the communication through the committee in School 2 was uni-directional; that is, the principal asked the committee members to come up with a plan to develop teachers but not necessarily in consultation with teachers, and moreover, the committee members felt it 'lacked the authority' to realise the TD plans they made.

\subsection{Collected DATA}

Data discussed in this paper include the results of individual and focus-group interviews with 24 teachers of different ranks at 2 Hong Kong secondary schools (11 and 13 teachers for Schools 1 21 
and 2, respectively) (see Table 3 for profiles of the teachers), as well as the records of the TD programmes provided to the schools by the Hong Kong Education Bureau (EDB) and other institutions between 1999 and 2013, interviews with head teachers and documents of the schools. The interview was chosen as the main data source as the aim of this research is to explore the relationships between teachers' views of reforms, the perceived features of the reforms and the TD the teachers could access for each reform. Other data were used for clarification and triangulation purposes.

The main themes of the interviews included key initiatives implemented over the past 15 years or so; how they had been implemented and their impact, if any; professional development and any other support provided for the reforms; and teachers' perceptions of the reforms over the course of those reforms (See Appendix for the interview schedule). The principal investigator and co-investigators conducted the interviews. An interview typically lasted for about an hour. Teachers who had first-hand experience with main reforms that had been implemented over the past 15 years were invited to participate; most of the teachers who accepted the invitation had 20 years of experience and over, and the 'youngest' teacher had 7 years of experience (see Table 3 for participant profiles). Semi-structured interviews were conducted to allow the pursuit of new significant themes identified during the interviews.

Table 3 Participant profiles

\begin{tabular}{|l|l|l|l|l|l|}
\hline School 1 & \multicolumn{2}{|l|}{ School 2 } \\
\hline Participant & Subject & $\begin{array}{l}\text { *Years of } \\
\text { teacher } \\
\text { experience }\end{array}$ & Participant & Subject & $\begin{array}{l}\text { *Years of } \\
\text { teacher } \\
\text { experience }\end{array}$ \\
\hline Key Staff 1 & Chemistry & $10-19$ & Key Staff 1 & Math & 20 or over \\
\hline
\end{tabular}




\begin{tabular}{|l|l|l|l|l|l|}
\hline Key Staff 2 & Math & 20 or over & Key Staff 2 & Chinese; Civic Ed. & 20 or over \\
\hline Key Staff 3 & English & 20 or over & Key Staff 3 & Chinese & 20 or over \\
\hline Key Staff 4 & Chemistry & 20 or over & Key Staff 4 & $\begin{array}{l}\text { Cross-curricular; } \\
\text { Math }\end{array}$ & 20 or over \\
\hline Key Staff 5 & Physics & 20 or over & Key Staff 5 & ICT; Math & 20 or over \\
\hline Teacher A & English & Less than 10 & Key Staff 6 & Physics & 20 or over \\
\hline Teacher B & Maths & $10-19$ & Teacher A & Physical Ed. & Less than 10 \\
\hline Teacher C & Chinese & 20 or over & Teacher B & Chinese & 10 -19 \\
\hline Teacher D & $\begin{array}{l}\text { Liberal } \\
\text { Studies }\end{array}$ & Less than 10 & Teacher C & Chinese History & 20 or over \\
\hline Teacher E & Physical Ed. & 20 or over & Teacher D & English & 20 or over \\
\hline Teacher F & Economics & $10-19$ & Teacher E & Geography & 20 or over \\
\hline & & & Teacher F & English & $10-19$ \\
\hline & & & Teacher G & Visual Arts & Less than 10 \\
\hline
\end{tabular}

*To ensure confidentiality, years of experience are presented only in ranges.

\subsection{DATA ANALYSis PROCEDURE}

The data analysis comprised three phases. First, educational reforms led by the government and implemented in the two case schools were selected and categorised by stakeholders' initial perceptions of policy ambiguity and conflict (see Table 4 for reform categorisations). When discussed separately, the individual initiatives subsumed under a larger overarching reform were counted independently. For instance, although SBA formed a part of the HKDSE examination, the two were counted as separate reforms. The participants in both schools used the former term to refer to the assessment conducted in individual schools and the latter to indicate the territorywide college entrance examination.

Table 4 Reform categorisations

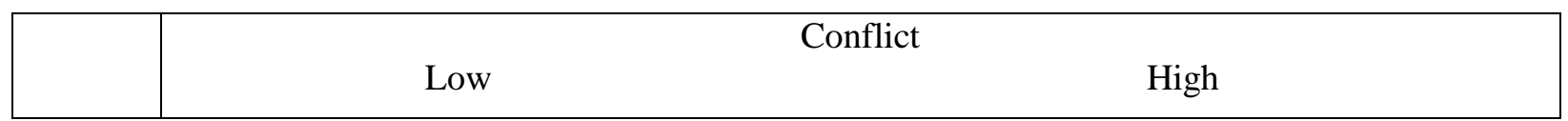




\begin{tabular}{|c|c|c|}
\hline 党 & $\begin{array}{l}\text { - English as the Medium of Instruction } \\
\text { (Schools } 1 \text { and 2) } \\
\text { - Information Technology (Schools } 1 \text { and 2) } \\
\text { - School-based Assessment (School 2) } \\
\text { - Liberal Studies (School 2) } \\
\text { - Other Learning Experience (School 1) }\end{array}$ & - Other Learning Experience (School 2) \\
\hline $\begin{array}{l}\overline{60} \\
\stackrel{60}{7}\end{array}$ & $\begin{array}{l}\text { - Collaborative Learning (School 1) } \\
\text { - Hong Kong Diploma of Secondary } \\
\text { Education (Schools } 1 \text { and 2) } \\
\text { - New Senior Secondary Curriculum (School } \\
\text { 1) } \\
\text { - Liberal Studies (School 1) }\end{array}$ & $\begin{array}{l}\text { - Collaborative Learning (School 2) } \\
\text { - New Senior Secondary Curriculum } \\
\text { (School 2) } \\
\text { - School-based Assessment (School 1) }\end{array}$ \\
\hline
\end{tabular}

Second, the TD provisions accessed by teachers were listed according to the corresponding reforms, and the match between those provisions and reform types in terms of ambiguity and conflict generation was analysed (see Table 5). Third, the participants' perceptions of select reforms after their implementation were compared across the two schools (see Table 6). ${ }^{4}$ To ensure analysis validity and reliability, all of the interview data were initially coded by three researchers, and the themes were collaboratively developed. Once the coding scheme was developed, the data were reanalysed independently by at least two researchers, and if any variance was found, each case was discussed by those who coded that part of the data.

Table 5 Match between reform types and TD provision in terms of ambiguity and conflict

\begin{tabular}{|l|l|l|l|l|}
\hline Names of the reform & $\begin{array}{l}\text { Case } \\
\text { Schools }\end{array}$ & $\begin{array}{l}\text { Type of } \\
\text { reform }\end{array}$ & $\begin{array}{l}\text { Type of TD } \\
* \text { N/D (No data) }\end{array}$ & $\begin{array}{l}\text { Type match } \\
\text { between }\end{array}$ \\
\hline
\end{tabular}

\footnotetext{
${ }^{4}$ There is limitation in the perception data, as teachers were not asked to discuss all eight reforms.
} 


\begin{tabular}{|c|c|c|c|c|}
\hline & & $\begin{array}{l}1 \text { Low am } \\
2 \text { High an } \\
3 \text { Low am } \\
4 \text { High an }\end{array}$ & $\begin{array}{l}\text { nflict } \\
\text { onflict } \\
\text { onflict } \\
\text { onflict }\end{array}$ & $\begin{array}{l}\text { reform and } \\
\text { TD }\end{array}$ \\
\hline \multirow[t]{2}{*}{ English as a Medium of Instruction } & School 1 & 1 & 1 & Yes \\
\hline & School 2 & 1 & N/D & No \\
\hline \multirow[t]{2}{*}{ Collaborative Learning } & School 1 & 2 & 1,2 & Yes \\
\hline & School 2 & 4 & 1,2 & $\mathrm{No}$ \\
\hline \multirow[t]{2}{*}{ Information \& Technology } & School 1 & 1 & 1 & Yes \\
\hline & School 2 & 1 & 1 & Yes \\
\hline \multirow[t]{2}{*}{ New Senior Secondary Curriculum } & School 1 & 2 & 1,2 & Yes \\
\hline & School 2 & 4 & 1 & No \\
\hline \multirow[t]{2}{*}{ School-based Assessment } & School 1 & 4 & $1,2,3$ & No \\
\hline & School 2 & 1 & 1 & Yes \\
\hline \multirow{2}{*}{$\begin{array}{l}\text { Hong Kong Diploma of Secondary } \\
\text { Education }\end{array}$} & School 1 & 2 & 1,2 & Yes \\
\hline & School 2 & 2 & 1 & No \\
\hline \multirow[t]{2}{*}{ Liberal Studies } & School 1 & 2 & 1,2 & Yes \\
\hline & School 2 & 1 & N/D & No \\
\hline \multirow[t]{2}{*}{ Other Learning Experience } & School 1 & 1 & N/D & No \\
\hline & School 2 & 3 & 1,3 & Yes \\
\hline
\end{tabular}

For the first phase, we coded teacher comments that reflected unclear, ambivalent, varied and inadequate understandings of the goals and means of the reforms as manifestations of a high degree of ambiguity, and considered the absence of such comments, adequate and accurate descriptions of reform policies and comments expressing a clear understanding of policies as signs of a low degree of ambiguity, as initially perceived by teachers. The following two comments were coded as instances of high and low degrees of ambiguity, respectively.

The requirements, including the depth and width of the Independent Enquiry Study, were unclear. (Teacher D, School 2)

Actually, we had been doing various things that they would regard as OLE, so we didn't need to introduce anything additional to meet the requirement. (Key Staff 2, School 1) 
The notion of conflict refers to incongruence or incompatibility between actors' beliefs and principles and the methodologies or schools of thought embodied in the reforms. Reports of controversy, resistance or discomfort that could have hindered the implementation of a reform were coded as having a high degree of conflict, whereas those indicating acceptance or reflecting alignment between reforms and participants' educational beliefs and current practices were coded as having a low degree of conflict. The following first extract is a high-conflict example, and the second is a low-conflict example.

We were not too happy with the SBA of LS because the Hong Kong Examination and Assessments Authority was to use the students' exam scores to moderate the scores for the SBA. Somehow we thought this was not the real spirit of having the SBA. (Teacher D, School 1)

For the [New Senior Secondary] curriculum, I think teachers welcomed the change. (Key Staff 4, School 1)

For the second phase, the types of TD provisions made for each identified reform were categorised in accordance with the respective features in the proposed framework (Table 1). Talks, one-off courses and seminars and discussions without actual coaching on teaching (e.g., committee meetings) were categorised as informative TD. Experiential TD was operationalised as programmes that allowed discussion of teachers' actual trials of reform concepts in their own classrooms, including supervised action research, reflection courses, discussion of the promoted pedagogy involving peer or mentor observation, co-planning and discussion-based sharing sessions. Negotiatory TD comprised training with elements of surveys and consultation through 
which teachers were able to express their opinions on the reforms and receive feedback; TD provision for a reform was coded as experiential and negotiatory when one particular programme had both elements of experiential and negotiatory TD, or when concurrently or subsequently offered TD programmes collectively addressed these aspects. In rare cases in which participants provided no information on the content of a programme and we had no way of determining that content, we left the programme uncoded and treated it as missing data.

For the final phase, when teachers expressed positive perceptions after the implementation (e.g., confidence in their ability to conduct the particular reform) or if they expressed their ownership of the reform, the perceptions were coded as positive; when they expressed ambivalent or conflicting views or did not express any personal position on the reform, the perceptions were coded as neutral; and when they criticised or complained about the reform from the perspective of either a teacher or a student, the perceptions were coded as negative. The following are examples of a positive, a neutral and a negative comment, respectively.

As I said before, our teachers are well trained, so there is nothing wrong. There is no challenge at all but the content, how to deal with the delivery. So I think teachers find it an easy task. No challenge at all. (Key Staff 4, School 1)

For CL, we cannot use it a lot because of the limited teaching time. However, we also enjoy this pedagogy because it allows us to have some kind of group discussion. (Key Staff 2, School 1) 
It's a pity. You can't blame a school for whether it has done well. It depends on the general environment. The school is helpless. We can only do something we think is correct. There are many things that we don't know. It's unlucky. (Key Staff 3, School 2)

\subsection{FINDINGS AND DISCUSSION}

Before we discuss the findings, the authors would like to reiterate our position about reforms, which was discussed in the introduction, that we do not believe that all reforms are improvements. We are aware that some reforms are not well prepared and all reforms become something different once they enter the reform context, and therefore, their legitimacy should be established before implementation and re-examined regularly. The discussion concerns when at least some consensus was made about the need or benefits of the reform, may it be fragmented and temporal.

\subsubsection{Customising TD provision to reform features and perceptions of reforms}

Eight reforms were commonly implemented in the two case study schools (see Table 2) and were categorised according to teachers' initial perceptions of them in terms of ambiguity and conflict, as shown in Table 4. The EDB and other education-related institutes, such as local universities, provided the majority of TD programmes accessed by teachers. However, others were organised by the schools themselves. For instance, for some of the reforms characterised by a high degree of ambiguity, such as CL and NSSC, external institutions did not offer experiential TD. School 1 arranged in-house TD sessions to compensate for the absence, which was not the case in School 2. 
As Table 5 shows, in School 1, the TD provisions were aligned with reform features - in terms of ambiguity and conflict generation - for six out of eight reforms, whereas in School 2 the alignment occurred only for three reforms. In School 1, teachers had access to experiential TD programmes such as common lesson preparation, mentoring, learning circles and reflective or fine-tuning workshops for all reforms with ambiguity (e.g., HKDSE) and negotiatory TD programmes such as a consultationary seminar for a reform with conflict generation (i.e., SBA).

For example, for the SBA, which was perceived as "really frightening," to borrow a teacher's description - indicating a high degree of conflict - School 1 provided "a period of consultation" where teachers expressed their concerns through the TD committee to the principal. Perhaps partly owing to the two-way dialogue, the principal had a very realistic gauge of the impact of the reform on teachers and students, which led her to avoid immediate full-scale implementation of the SBA in her school. As she noted:

I argued for not implementing SBA at such a quick pace. I asked to have a look at the matrix of what a student needed to face in the next few years...how many assessments, subjects, learning activities they would be asked to do. SBA is hard for both students and teachers. It is very idealistic. Different subjects viewed SBA differently, philosophically differently. (Principal, School 1)

In contrast, in School 2, the TD provision for reforms with high ambiguity (e.g., HKDSE where "no teacher understood what it was about") was informative (e.g., provision of guidelines) or pseudo-experiential (e.g., in-school TD in which teachers engaged in self-evaluation without practical assistance such as observations or mentoring). For all reforms with high degrees of conflict (e.g., Collaborative Learning), mentions of negotiatory TD were absent, with the 29 
exception of OLE, for which the key staff in charge attended an extended seminar which involved a discussion of its rationale and necessity.

As Table 6 succinctly shows, the overruling perceptions of a reform were positive, neutral or ambivalent as a group when there was a match between the initially perceived reform features and the TD provision. When there was a mismatch, the dominant views were negative. In cases where the reform was highly ambiguous and this was not addressed in TD, teachers reported a lack of competence (e.g., "The requirements are out of reach.”), exhaustion (“Take LS for example. We were worn out with related errands... because we did not understand how it would really be implemented in the future."), resource waste (e.g., "Many 'grand' projects were produced, but in the end it was found to be unnecessary.") and superficial implementation (e.g., "For CL, teachers just divided the students into a few groups because they did not have formal training."). When the TD did not address the high degree of conflict generated by a reform, they reported emotional costs (e.g., "The most important thing is that it makes good teachers lose their interest in teaching."), and even the drastic decision to leave the profession (e.g., "A group of teachers [with good ethics] had left already.").

Table 6 Match between reform types and TD provision and perceptions of the reform

\begin{tabular}{|c|c|c|c|c|c|c|}
\hline \multirow{2}{*}{$\begin{array}{l}\text { Names of the reform } \\
\text { (number of teachers } \\
\text { commenting on the reform) }\end{array}$} & \multirow{2}{*}{$\begin{array}{l}\text { Type } \\
\text { of } \\
\text { reform }\end{array}$} & \multirow[t]{2}{*}{$\begin{array}{l}\text { Type of } \\
\text { TD }\end{array}$} & \multirow{2}{*}{$\begin{array}{l}\text { Type } \\
\text { match } \\
\text { between } \\
\text { reform } \\
\text { and TD }\end{array}$} & \multicolumn{3}{|c|}{$\begin{array}{c}\text { Views of reforms } \\
\text { after implementation }\end{array}$} \\
\hline & & & & Positive & Ambivalent & Negative \\
\hline \multicolumn{7}{|c|}{ School 1} \\
\hline $\begin{array}{l}\text { English as a Medium of } \\
\text { Instruction }(n=4)\end{array}$ & 1 & 1 & Yes & 3 & 0 & 1 \\
\hline Collaborative learning $(n=9)$ & 2 & 1,2 & Yes & 1 & 8 & 0 \\
\hline
\end{tabular}




\begin{tabular}{|c|c|c|c|c|c|c|}
\hline $\begin{array}{l}\text { Information \& Technology (n } \\
=1)\end{array}$ & 1 & 1 & Yes & 1 & 0 & 0 \\
\hline $\begin{array}{l}\text { New Senior Secondary } \\
\text { Curriculum }(\mathrm{n}=7)\end{array}$ & 2 & 1,2 & Yes & 1 & 4 & 2 \\
\hline $\begin{array}{l}\text { School-based Assessment }(\mathrm{n}= \\
6 \text { ) }\end{array}$ & 4 & $1,2,3$ & No & 0 & 1 & 5 \\
\hline $\begin{array}{l}\text { Diploma of Secondary } \\
\text { Education }(\mathrm{n}=9)\end{array}$ & 2 & 1,2 & Yes & 4 & 2 & 3 \\
\hline Liberal Studies $(\mathrm{n}=2)$ & 2 & 1,2 & Yes & 1 & 1 & 0 \\
\hline $\begin{array}{l}\text { Other Learning Experience ( } \mathrm{n} \\
=1 \text { ) }\end{array}$ & 1 & 0 & No & 0 & 1 & 0 \\
\hline \multicolumn{7}{|c|}{ School 2} \\
\hline $\begin{array}{l}\text { English as a Medium of } \\
\text { Instruction }(n=7)\end{array}$ & 1 & 0 & No & 2 & 3 & 2 \\
\hline Collaborative learning $(\mathrm{n}=9)$ & 4 & 1,2 & No & 0 & 0 & 9 \\
\hline $\begin{array}{l}\text { Information \& Technology ( } \\
=4)\end{array}$ & 1 & 1 & Yes & 1 & 2 & 1 \\
\hline $\begin{array}{l}\text { New Senior Secondary } \\
\text { Curriculum }(\mathrm{n}=11)\end{array}$ & 4 & 1 & No & 0 & 3 & 8 \\
\hline $\begin{array}{l}\text { School-based Assessment }(\mathrm{n}= \\
\text { 5) }\end{array}$ & 1 & 1 & Yes & 0 & 1 & 4 \\
\hline $\begin{array}{l}\text { Diploma of Secondary } \\
\text { Education }(\mathrm{n}=1)\end{array}$ & 2 & 1 & No & 0 & 0 & 1 \\
\hline Liberal Studies $(\mathrm{n}=2)$ & 1 & 0 & No & 1 & 0 & 1 \\
\hline $\begin{array}{l}\text { Other Learning Experience ( } \mathrm{n} \\
=3 \text { ) }\end{array}$ & 3 & 1,3 & Yes & 1 & 1 & 1 \\
\hline
\end{tabular}

* Greyed cells represent overriding perceptions

However, there were a couple of exceptions. In School 1, where OLE had long been practised, there was no provision of TD but the perception was neutral, perhaps because it was not a reform to the school. For School 2, SBA was initially considered to be clear-cut, and teachers accepted the reform without expressing any resistance. However, after 3 years of implementation, the majority of teachers expressed their concerns about SBA as follows.

Old teachers like me with bad eyesight can hardly mark papers. When that happens, experienced teachers stop marking papers. When there is a meeting for marking, all of the 
young teachers attend. I am not saying that young teachers are not good. But they are not experienced...so the range of marks can be very big now. Everything is fine, and they just mark carelessly. It's a problem. (Key Staff 3, School 2)

SBA has to be cut... Now a structure is lacking. Should SBA run once only? This is similar to the exam, and there should be one chance only. Formative assessment, however, is difficult to handle, though it is school-based. Actually, only a performance is marked, and we cannot see if this is really a formative assessment. (Teacher F, School 2)

This suggests that customising TD to perceived reform features should be an on-going process; while the reform is being implemented, other issues may arise that were not expected in the beginning. For instance, Key Staff 3 pointed out the unexpected role division between young and senior teachers, which created a new need for TD provision, that is, developing young teachers' capacity to mark fairly and thoroughly. Teacher F also showed that the formative assessment, an important aspect of the SBA, was very narrowly conceptualised by teachers, an issue that could be addressed in part by providing TD on what constitutes formative assessment.

Overall, the reforms discussed in the teacher interviews tended to be described in positive or neutral terms in School 1, but not in School 2, as can be seen in Table 6. In School 1, although some expressed negative views after their initial implementation, at least they were not the majority - except for the SBA reform, for which there was a mismatch between the reform features and the TD provision. In contrast, of the eight reforms discussed by the staff of School 2, half were perceived negatively by the majority, and one change received bipolar views, and no reforms were viewed positively on the whole. 


\section{CONCLUSION, IMPLICATIONS AND FUTURE RESEARCH}

The aim of this paper was to reduce the range of factors which affect the trajectory of a reform into limited key factors, and the literature review and the empirical study showed that among other features of a reform, the degree of ambiguity and conflict generation can be such main factors, although the data also suggests that other factors such as leadership practices, teachers' beliefs, and contextual features complicate the way these two features shape the ways a reform is enacted, and responded to.

The two, ambiguity and conflict generation, being the key factors, it was suggested that they be addressed in TD provision for a particular reform by the government or other system level reforms. Then a heuristic framework was proposed for customising TD provision to reform features (Table 1), drawing on a review of the research on educational reform and teacher cognition, change and development (e.g., Day et al., 2005; Kubanyiova, 2009; Matland, 1995; O'Donahue, 2012). To examine the utility of the framework, two Hong Kong schools' TD provision for eight major reforms and teachers' perceptions of the reforms were analysed. The case study showed that, in general and as predicted by the framework, when TD was matched to perceived reform features in terms of ambiguity and conflict generation when it was first introduced, teachers as a group developed positive or at least neutral/ambivalent views of a reform after its implementation, whereas when misalignment occurred teachers tended to have negative views of the reforms (Table 6).

The findings indicate that the proposed framework for providing customised TD (Table 1) may be used as a guide for choosing, devising and modifying TD for different reforms based on the perceptions of the reforms gathered at their initial stages. As postulated in the framework, in 
the case schools, the basic knowledge, skills and resources delivered by informative TD were sufficient to support teachers implementing reforms with low levels of ambiguity and conflict when the initial assessment was accurate - as shown through positive perceptions of reforms coinciding with such provision. When the ambiguity levels rise, one-off TD is insufficient for teachers to clearly understand goals and means to implement the reform, resulting in a lack of competence, emotional cost, waste of resources and superficial implementation, in contrast to when hands-on experience with the contextualised support provided by experiential TD is given. When policy goals and means are comprehensible but initially opposed by the actors involved, the key to successful policy enactment is identifying and addressing the sources of the conflict by engaging in negotiation with teachers through negotiatory TD. Negotiatory TD should also provide support by addressing the emotional unrest that accompanies adopting pedagogic change, which involves changing pedagogic beliefs and identities. For reforms where the degrees of both ambiguity and conflict are high, a combination of experiential and negotiatory TD coexists with positive views on the reforms. The two cases where the prediction from this framework did not work, however, communicated the following: first, the possibility that teachers may not always gauge the reforms appropriately at the initial stage of the reform, or that new needs may be created as the reform unfolds, and second, TD needs are context-specific, as some initiatives are not at all new for some schools.

The findings have the following practical implications. Reform managers would well do to assess the initial degrees of ambiguity and conflict surrounding a policy before its actual implementation by adopting such measures as stakeholder surveys or focus group interviews. Doing so would provide not only insights into what type of TD should be provided, but also 
structural information on the potential problems and legitimacy of the policy itself. Considering that the initial perceptions of the same reforms differed across the case study schools, the government may want to explore the need for providing school-specific TD. A recent review of TD research of the past decade (Avalos, 2011) also notes this school-specific nature of TD. An initiative called 'school-visiting TD' or 'tailored TD' that has been practised in South Korea since 2010 is one such example. South Korean schoolteachers can form a learning group and submit a proposal for TD that addresses their developmental needs to government-designated TD institutes, and the institutes design the requested TD and conduct it by dispatching teacher trainers. The differential access to TD provisions between the two schools may also point to the need for the main providers of TD programmes such as the EDB to engage in promotion of their programmes. However, it should also be noted that the initial understanding of the reforms was not always accurate, and thus, that TD provision should also be reviewed on an on-going basis.

There are also theoretical implications for reform studies. It is often assumed that one particular initiative will be experienced similarly across schools. However, as Table 4 shows, each reform was perceived differently - depending on factors such as the schools' historical relationship with the initiative, and teachers' background and competencies existent within a school. These came together to create different needs across the schools. Therefore, future reform studies may incorporate this situated, context-specific nature of reforms. Also, even within a same school, staff with different backgrounds (e.g., young or more senior teachers) experienced individual reforms differently, and therefore, discussion of TD in a reform context should integrate this personalised nature of TD needs. Finally, this study tried to respond to the call by Spillane (2012) for researchers of TD in a reform context to transcend the dual narratives 
which pressure them to take sides with either the camp that espouses absolute respect for the expertise and professionalism of teachers, or the other which demands reform initiators and managers to take full charge to break the inertia in teachers' pedagogic practices: we tried to bring together the two contending positions in identifying effective TD provision, by analysing and categorising reforms from teachers' experiential perspectives, and making suggestions from reform initiators and managers. After all, reforms can only work when both parties are brought to the table of negotiation.

To consider the limitations of the current study, the following may inform future research projects. First, the findings were drawn from an in-depth case study of two schools; to examine the generalisability of the findings, a large-scale survey study would be useful. Such study could explore the extent to which teachers' perceptions of the reforms are explained by ambiguity and conflict generation, and whether other reform characteristics should be added. Second, the TD experiences were based on teacher reports. Given that the teachers were asked to revisit the past decade, they might have failed to report a TD provision, or not discussed a particular reform. More thorough results could be obtained by requesting the TD records of individuals, if such records exist, or conducting a long-term study using standardised interviews or surveys, or through an intervention study. It is hoped that this study can make a meaningful step toward theorising an effective TD provision in the reform context, reflecting the complexities involved.

\section{REFERENCES}

Authors 2011 [details removed for peer review] Authors 2014 [details removed for peer review] 
Authors 2015 [details removed for peer review]

Authors 2016 [details removed for peer review]

Authors 2017a [details removed for peer review]

Authors 2017b [details removed for peer review]

Authors 2017c [details removed for peer review]

Advisory Committee on Teacher Education and Qualifications (2009). Towards a learning profession: Third report on teachers' continuing professional development. Hong Kong: Advisory Committee on Teacher Education and Qualifications.

Andrews, C. J. (2007). Rationality in policy decision making. In F. Fischer, G. J. Miller, \& M. S. Sidney (Eds.), Handbook of public policy analysis : Theory, politics, and methods (pp. 161-171). Hoboken, NJ: CRC Press.

Avalos, B. (2011). Teacher professional development in Teaching and Teacher Education over ten years. Teaching and Teacher Education, 27(1), 10-20.

Ball, S. J. (1990). Politics and policy making in education: Explorations in policy sociology. London and New York: Routledge.

Ball, S. J., Maguire, M., \& Braun, A. (2012). How schools do policy: Policy enactments in secondary schools. London: Routledge.

Cheng, Y.-C. (2013). Educational reform and professional development: Paradigm shift and international syndrome. In I. R. Haslam, M. S. Khine, \& I. M. Saleh (Eds.), Large scale school reform and social capital building (pp. 217-239). New York: Routledge.

Cohen, L., Manion, L., \& Morrison, K. (2011). Research methods in education. London and New York: Routledge. 
Cummins, J. (2013). The role of research on literacy, poverty, and diversity in transforming schools. In R. A. DeVillar, B. Jiang, \& J. Cummins (Eds.), Transforming education: Global perspectives, experiences, and implications (pp. 17-39). New York: Peter Lang Publishing.

Day, C., Elliot, B., \& Kington, A. (2005). Reform, standards and teacher identity: Challenges of sustaining commitment. Teaching and Teacher Education, 21(5), 563-577.

Denzin, N. K., \& Lincoln, Y. S. (2011). Introduction: The discipline and practice of qualitative research. In N. K. Denzin \& Y. S. Lincoln (Eds.), The Sage handbook of qualitative research (4th ed., pp. 1-19). Thousand Oaks, CA: Sage.

Duff, P. (2008). Case study research in applied linguistics. NY: Lawrence Erlbaum.

Fennema, E., Carpenter, T. P., Franke, M. L., Levi, L., Jacobs, V. R., \& Empson, S. B. (1996). A longitudinal study of learning to use children's thinking in methematics instruction. Journal for Research in Mathematics Education, 27(4), 403-434.

Flyvbjerg, B. (2011). Case study. In N. K. Denzin \& Y. S. Lincoln (Eds.), The sage handbook of qualitative research (pp. 301-316). Thousand Oaks, CA: Sage Publications, Inc.

Fullan, M. (2001). The new meaning of educational change. New York: Teacher's College, Columbia University.

Fullan, M. (2009). Large-scale reform comes of age. Journal of Educational Change, 10(2-3), $101-113$.

Fullan, M., \& Hargreaves, A. (2013). Teacher development and educational change. In M. Fullan \& A. Hargreaves (Eds.), Teacher development and educational change (pp. 1-9). Oxon: Routledge. 
Garet, M. S., Porter, A. C., Desimone, L., Birman, B. F., \& Yoon, K. S. (2001). What makes professional development effective? Results from a national sample of teachers. American Educational Research Journal, 38(4), 915-945.

Graves, K. (2009). The curriculum of second langauge teacher education. In A. Burns \& J. C. Richards (Eds.), The Cambridge guide to second language teacher education (pp. 115124). Cambridge: Cambridge University Press.

Gunter, H., Rayner, S., Butt, G., Fielding, A., Lance, A., \& Thomas, H. (2007). Transforming the school workforce - perspectives on school reform in England. Journal of Educational Change, 8(1), 25-39.

Guskey, T. R. (2000). Evaluating professional development. Thousand Oaks, CA: Corwin Press, Inc.

Hall, C., \& Noyes, A. (2009). New regimes of truth: The impact of performative school self evaluation systems on teachers' professional identities. Teaching and Teacher Education, $25(6), 850-856$.

Hammerness, K., Darling-Hammond, L., Bransford, J. with Berliner, D., Cochran-Smith, M., McDonald, M., \& Zeichner, K. (2005). How teachers learn and develop. In L. DarlingHammond \& J. Bransford (Eds.), Preparing teachers for a changing world: What teachers should learn and be able to do (pp. 358-389). San Francisco: John Wiley \& Sons.

Hargreaves, A. (2001). Emotional geographies of teaching. Teachers College Record, 103(6), 1056-1080. 
Hayes, D. (2012). Mismatched perspectives: In-service teacher education policy and practice in South Korea. In C. Tribble (Ed.), Managing change in English language teaching: Lessons from experience (pp. 99-104). London: British Council.

Heo, H., Lim, K. Y., Lee, H. W., \& Kim, H. (2014). 스마트교육을 위한 교원의 교육요구도 분석[A Needs Analysis of Teacher Competencies for SMART Education]. Korean Journal of Teacher Education, 30(1), 93-112.

Hill, H. C., Beisiegel, M., \& Jacob, R. (2013). Professional development research: Consensus, crossroads and challenges. Educational Researcher, 42(9), 476-487.

Hu, G., \& McKay, S. L. (2012). English language education in East Asia: Some recent developments. Journal of Multilingual and Multicultural Development, 33(4), 345-362.

Hyun, J. Hwang., Kim, J.-S., Jang, D.-H., \& Han, S.-Y. (2010). 교육정책 현장착근을 위한 매뉴얼 개발 방안 연구 [Research on development of policy manual for policy implementation and embedment]. Seoul: Korea Educational Development Institute.

Lee, J. H. (2011). ICT R\&D and policy in Korea: Focused on ICT convergence. Paper presented at the 2011 Internatinoal Conference, Brussels, Belgium.

Lee, S.-Y., \& Lee, Y. (2015). Analysis of elementary teachers' readiness for smart learning in Korea. In G. Chen, V. Kumar, K. R. Huang, \& S. C. Kong (Eds.), Emerging issues in smart learning: Lecture notes in educational technology (pp. 77-84). Berlin, Germany: Springer.

Im, Y.-K. (2008). Issues and tasks of teacher evaluation policy. The Journal of Korean Education, 35, 195-216. 
International Telecommunication Union. (2012). Measuring the information society. Geneva: International Telecommunication Union.

Jann, W., \& Wegrich, K. (2007). Theories of the policy cycle. In F. Fischer, G. J. Miller, \& M. S. Sidney (Eds.), Handbook of public policy analysis: Theory, politics, and methods (pp. 4362). Hoboken, NJ: CRC Press.

Jeon, J. S. (2010). 교원능력개발평가의 도입 배경과 향후전망 [Institution of and prospect for the Teacher Appraisal for Professional Development]. Seoul: Ministry of Education Science and Technology.

Jeong, B. R. (2012, April 17). 현직 교사들이 말하는 '디지털 교과서' [Digitalised textbooks from the perspectives of teachers], Bloter. Retrieved from http://www.bloter.net/archives/105653

Kan, V., \& Adamson, B. (2016). A matrix approach to language policy analysis: The case of Hong Kong. In C.-M. Lam \& J. Park (Eds.), Sociological and philosophical perspectives on education in the Asia-Pacific region (Vol. 29) (pp. 111-130). Singapore: Springer.

Kaniuka, T. S. (2012). Toward an understanding of how teachers change during school reform: Considerations for educational leadership and school improvement. Journal of Educational Change, 13(3), 327-346.

Kiely, R., \& Davis, M. (2010). From transmission to transformation: Teacher learning in ESOL. Language Teaching Research, 14(3), 277-295.

Kim, J. D. (2012, July 17). 체계적인 콘텐츠로 무장 더 똑똑한 교실 만들게요 [We promise a smarter classroom through developing systematic contents of the lesson], Chonsun Daily. 
Retrieved from

http://news.chosun.com/site/data/html_dir/2012/07/15/2012071500650.html

Kim, S. T. (2011). 교원능력개발평가 제도의 운영성과 분석: 시범학교를 중심으로

[Analysis of outcome of the Teacher Appraisal for Professional Development: Focusing on lead schools]. Korean Public Personnel Administration Review, 10, 187-217.

Korea Educational Development Institute (2010). 2010 교육정책 네트워크

교육현장순회토론회(충청북도교육청) 교원능력개발평가제도의 현장 적합성 검토 [2010 Educational policy netweork debate tour (Chungcheongbuk-do Educational Office): Examining the feasibility of the Teacher Appraisal for Professional Development]. Seoul: Korea Educational Development Institute.

Korthagen, F. A. J., \& Kessels, J. P. A. M. (1999). Linking theory and practice: Changing the pedagogy of teacher education. Educational Researcher, 28, 4-17.

Kubanyiova, M. (2009). Possible selves in language teacher development. In Z. Dörnyei \& E. Ushioda (Eds.), Motivation, language identity and the L2 self (pp. 314-332). Bristol [England] : Multilingual Matters.

Lamb, M. (1995). The consequences of INSET. ELT Journal, 49(1), 72-80.

Lamie, J. M. (2004). Presenting a model of change. Language Teaching Research, 8(2), 115-142.

Leithwood, K., Jantzi, D., \& Mascall, B. (2002). A framework for research on large-scale reform. Journal of Educational Change, 3(1), 7-33.

Markee, N. (1997). Managing curricular innovation. Cambridge: Cambridge University Press. 
Matland, R. E. (1995). Synthesizing the implementation literature: The ambiguity-conflict model of policy implementation. Journal of Public Administration Research and Theory, 5(2), $145-174$.

McNeil, L. M., \& Coppola, E. M. (2006). Official and unofficial stories: Getting at the impact of policy on educational practice. In J. L. Green, G. Camilli \& P. B. Elmore (Eds.), Handbook of complementary methods in education research (pp. 681-700). Mahwah, NJ: Lawrence Erlbaum Associates, Inc.

Menken, K., \& García, O. (Eds.). (2010). Negotiating language policies in schools: Educators as policymakers. New York, NY: Routledge.

Ministry of Education Science and Technology. (2012). 안정적 정착을 위한2012 년 교원능력 개발 평가 개선 방안 [2012 Revision of the Teacher Appraisal for Professional Development]. Seoul: Ministry of Education Science and Technology.

Mourshed, M., Chijioke, C., \& Barber, M. (2010). How the worlds' most improved school systems keep getting better. Retrieved from http://mckinseyonsociety.com/downloads/reports/Education/How-the-Worlds-MostImproved-School-Systems-Keep-Getting-Better_Download-version_Final.pdf

Muijs, D., \& Lindsay, G. (2008). Where are we at? An empirical study of levels and methods of evaluating continuing professional development. British Educational Research Journal, $34(2), 195-211$.

Murray, D. E., \& Christison, M. (2012). Understanding innovation in English language education: Contexts and issues. In C. Tribble (Ed.), Managing change in English language teaching: Lessons from experience (pp. 61-74). London, UK: British Council. 
Nishino, T. (2008). Japanese secondary school teachers' beliefs and practices regarding communicative language teaching: An exploratory survey. JALT Journal, 30(1), 27-50.

O'Donahue, C. (2012). Change in Tamil Nadu, India. In C. Tribble (Ed.), Managing change in English language teaching: Lessons from experience (pp. 153-157). London: British Council.

OECD [The Organization for Economic Cooperation and Development]. (2015). OECD Education Policy outlook 2015: Making reforms happen. Retrieved from http://www.oecd.org/edu/education-policy-outlook-2015-9789264225442-en.htm

Park, M., \& Sung, Y.-K. (2013). Teachers' perceptions of the recent curriculum reforms and their implementation: What can we learn from the case of Korean elementary teachers? Asia Pacific Journal of Education, 33(1), 15-33.

Pennington, M. C. (1995). The teacher change cycle. TESOL Quarterly, 29(4), 705-731.

Pennington, M. C. (1996). Modeling teacher change: Relating input to output. Hong Kong: City University of Hong Kong.

Pülzl, H., \& Treib, O. (2007). Implementing public policy. In F. Fischer, G. J. Miller, \& M. S. Sidney (Eds.), Handbook of public policy analysis: Theory, politics, and methods (pp. 89107). Hoboken: CRC Press. Retrieved from http://reader.eblib.com/\%28S\%283gf1gsugf2eyvot2pdtv05gf\%29\%29/Reader.aspx?p=28 3245\&o=1219\&u=B8yT1 cJQCg856LpCiNVQi7AZ6Zg\%3d\&t=1323868344\&h=DAE8 EE8589BE7EBC6030E2CDCF92F2B2E0343FFB\&s=11596963\&ut=4056\&pg=1\&r=im $\mathrm{g} \& \mathrm{c}=-1 \& \mathrm{pat}=\mathrm{n} \#$

Rizvi, F., \& Kemmis, S. (1987). Dilemmas of reform. Geelong Vic: Deakin University Press. 
Rubdy, R. (2008). Diffusion of innovation: A plea for indigenous models. TESL-EJ, 12(3), 1-34. Retrieved from http://tesl-ej.org/ej47/a2.pdf

Russell, T., \& Munby, H. (1992). Teachers and teaching: From classroom to reflection. London: The Falmer Press.

Sahlberg, P. (2006). Education reform for raising economic competitiveness. Journal of Educational Change, 7(4), 259-287.

Sakui, K. (2004). Wearing two pairs of shoes: Language teaching in Japan. English Language Teaching Journal, 58(2), 155-163.

Saunders, R. (2013). The role of teacher emotions in change: Experiences, patterns and implications for professional development. Journal of Educational Change, 14(3), 303333.

Schmidt, M., \& Datnow, A. (2005). Teachers' sense-making about comprehensive school reform: The influence of emotions. Teaching and Teacher Education, 21(8), 949-965.

Scott, C., \& Sutton, R. (2009). Emotions and change during professional development for teachers: A mixed methods study. Journal of Mixed Methods Research, 3(2), 151-171.

Seoul Gangnam District Office of Education. (2010). 2010 교원능력개발평가 우수사례 발표 안내 [2010 Case sharing of excellent implementation of the Teacher Appraisal for Professional Development]. Seoul: Seoul Gangnam District Office of Education.

Seoul Metropolitan Office of Education. (2010). 교원능력개발평가 성과 분석 및 모형 개선 연구 설문 참여 안내 [Survey on outcomes and areas for improvement of the Teacher Appraisal for Professional Development]. Seoul: Seoul Metropolitan Office of Education. 
Sikes, P. (1992). Imposed change and the experienced teacher. In M. Fullan \& A. Hargreaves (Eds.), Teacher development and educational change (pp. 36-55). London: The Falmer Press.

Smith, C., \& Gillespie, M. (2007). Research on professional development and teacher change: Implications for adult basic education. [Electronic version]. In J. Comings, B. Garner, \& C. Smith (Eds.), Review of adult learning and literacy, volume 7: Connecting research, policy, and practice (pp. 205-244). Mahwah, N.J.: Lawrence Erlbaum.

Spillane, J. P. (2004). Standards deviation: How schools misunderstand education policy. Cambridge: Harvard University Press.

Spillane, J. P., Reiser, B. J., \& Reimer, T. (2002). Policy implementation and cognition: Reframing and refocusing implementation research. Review of Educational Research, 72(3), 387-431.

Spillane, J. P. (2012). The more things change, the more things stay the same? Education and Urban Society, 44(2). 123-127.

Stake, R. E. (2005). Multiple case study analysis. Retrieved from http://reader.eblib.com/\%28S\%28qtlvhmjhvyatlqzmdmpoutbm\%29\%29/Reader.aspx?p= 362572\&o=1219\&u=B8yT1cJQCg856LpCiNVQi7AZ6Zg\%3d\&t=1361119098\&h=D74 B55AD9FE82B530899369F475B4DCC7ED0447E\&s=15827391\&ut=4056\&pg=1\&r=i $\operatorname{mg} \& \mathrm{c}=-1 \& \mathrm{pat}=\mathrm{n} \#$

Starr, K. (2011). Principals and the politics of resistance to change. Educational Management Administration \& Leadership, 39(6), 646-660. 
Stein, M. K., Silver, E. A., \& Smith, M. S. (1998). Mathematics reform and teacher development: A community of practice perspective. In J. G. Greeno \& S. V. Goldman (Eds.), Thinking practices in mathematics and science learning (pp. 17-52). Mahwah: Lawrence Erlbaum Associates.

Tang, S. Y. F. (2015a). The creeping of neo-liberal influences into teacher education policy: The case of Hong Kong. The Asia-Pacific Education Researcher, 24(2), 271-282.

Tang, S. Y. F. (2015b). Teachers' continuing professional development in Hong Kong: Policy, practice and issues. In K. G. Karras \& C. C. Wolhuter (Eds.), International handbook of teacher education training and re-training systems in modern world (pp. 180-197). Nicosia: HM Studies and Publishing.

Van Veen, K., \& Sleegers, P. (2006). How does it feel? Teachers' emotions in a context of change. Journal of Curriculum studies, 38(1), 85-111.

Van Veen, K., Sleegers, P., \& van de Ven, P.-H. (2005). One teacher's identity, emotions, and commitment to change: A case study into the cognitive-affective processes of a secondary school teacher in the context of reforms. Teaching and Teacher Education, 21(8), 917-934.

Vulliamy, G., Kimonen, E., Nevalainen, R., \& Webb, R. (1997). Teacher identity, curriculum change- a comparative case study analysis of small schools in England and Finland. Comparative Education, 33(1), 97-115.

Waters, A. (2009). Managing innovation in English language education. Language Teaching, 42(4), 421-458. 
Waters, A., \& Vilches, M. L. C. (2001). Implementing ELT innovations: A needs analysis framework. ELT Journal, 55(2), 133-141.

Waugh, R., \& Godfrey, J. (1993). Teacher receptivity to system-wide change in the implementation stage. British Educational Research Journal, 19(5), 565-578.

Wedell, M. (2009). Innovation in ELT. ELT Journal, 63(4), 397-399.

Wedell, M. (2012). The Oman BA project: ELT change implementation, process or event? In C. Tribble (Ed.), Managing change in English language teaching: Lessons from experience (pp. 171-175). London: British Council.

Woods, D. (1996). Teacher cognition in language teaching: Beliefs, decision-making and classroom practice. Cambridge: Cambridge University Press.

Woods, P. (2012). A summary of key lessons from the case studies. In C. Tribble (Ed.), Managing change in English language teaching: Lessons from experience (pp. 233-244). London: British Council.

Yi, H., \& Kwak, Y. (2009). 교원능력개발평가제 실시에 따른 수업 능력개발 요구 교사의 전문성 신장 지원 방안[Supports for under-performing teachers identified by the Teacher Appraisal for Professional Development]. Seoul: Korea Institute for Curriculum and Innovation.

Yin, R. K. (2009). Case study research: Design and methods (4th ed.). Thousand Oaks, CA.: Sage Publications, Inc.

Yook, C. M. (2010). Korean teachers' beliefs about English language education and their impacts upon the Ministry of Education-initiated reforms. Unpublished doctoral thesis, Georgia State University. 


\section{ApPendix. InTERVieW SCHEDULE}

Before our meeting, please think about your last 10 years in the schools:

What were 3-4 key changes that have occurred in the school?

What were 3-4 key targets for school improvement that you can remember working on?

What were 3-4 government reforms or policies that have had the greatest impact on the school?

\section{$\underline{\text { A. Initial questions }}$}

\section{A1. How long have you been in post in this school?}

\section{A2. Different phases of development of your school}

What has been changed in the school during that time?

Can you identify different phases of development of your school over the last ten years?

What were the main targets for your school to achieve in respective phases?

\section{A3. Most significant government policies}

Can you list two or three externally initiated government policies that you find most significant for your school over recent years?

How would you describe the current educational policy landscape?

Do you keep abreast of current policy developments/changes? How?

A4. How optimistic are you about the following:

Explain what makes you feel this way and give some examples

School

Pupils

Own career

49 
The profession

A5. How would you describe a) yourself and b) the wider staff in relation to the following:

Explain and give specific examples.

Ambition

Loyalty (to the school)

Pride (in the school)

\section{B. Main questions}

B1. Is there any clash between what policies require and what you want to do?

Do you believe in the policies you are asked to implement?

B2. Incorporating policies into your school

How much have the policies influenced the strategic direction of the school?

How do you align and integrate policies into the life of the school?

How do you facilitate these policies to improve the educational experience of the students in this school?

B3. How do you maintain focus on the teaching and learning agenda whilst accounting for policy changes?

Explain the situation in your school in relation to the following:

How much do school reforms and initiatives facilitate these obligations?

How much do school reforms and initiatives distract from these obligations?

\section{B4. Professional development}

What additional skills and resources have been needed to implement the reform?

50 
Have you engaged in any professional development to facilitate effective policy enactment across the school? What proportion of the CPD programme does this take up?

\section{B5. Communication within your school}

How do you articulate/communicate policy to your staff members? What about the students?

Is the culture of the school receptive to change?

\section{Impact}

\section{C1. Most significant government policies}

Which policies would you say have had the most influence on the success of the school? How?

Which one(s) resonate the most with you? Why?

\section{C2. Effects of policies}

How would you describe the effects of these policies in the following areas:

Job satisfaction (both yourself and the wider staff)

Sense of professionalism (both yourself and the wider staff)

Commitment (both yourself and the wider staff)

Teaching and learning agenda

Students

Overall effectiveness of the school

C3. How do you gauge the impact of a policy?

C4. If you were a policy maker, what would you do differently?

51 